\title{
Accountability from the Perspective of Malaysian Governance
}

\author{
Ahmad Faiz Yaakob \\ Faculty of Administrative Science and Policy Studies \\ Universiti Teknologi MARA Terengganu, 23000 Dungun, Terengganu \\ Tel: 60-12-222-7659 E-mail: faiziiu@yahoo.com \\ Nadhrah A. Kadir \\ Faculty of Administrative Science and Policy Studies \\ Universiti Teknologi MARA Terengganu, 23000 Dungun, Terengganu \\ Tel: 60-12-250-4302 E-mail: nadhr292@tganu.uitm.edu.my
}

Kamaruzaman Jusoff (Corresponding author)

TropAIR, Faculty of Forestry, Universiti Putra Malaysia, Serdang 43400, Selangor, Malaysia

Tel: 60-3-8946-7176 E-mail: kjusoff@yahoo.com

\begin{abstract}
Generally, accountability is often associated with a concept of answerability, responsibility, blameworthiness, liability etc. Commonly, the concept of accountability from the perspective of governance is the means to control the public administration in democratic countries. The classification of public accountability is normally seen in terms of external and internal mechanisms. Hence, this paper shall discuss both mechanisms with special reference to Malaysia. The discussion also focuses on the limitation of each mechanism which rendered some problems to the concept of accountability in Malaysia.
\end{abstract}

Keywords: Accountability, Governance, Public administration,

\section{Introduction}

Accountability is often associated with such concepts as answerability, responsibility, blameworthiness, liability and other terms associated with the expectation of accounting (Note 1). An individual who is accountable will be on his own commit to do or implement something if he feels that an occurrence or the result of the occurrence is important. It also involves effective reporting or program impact done to see the results and changes experienced from the aspect of knowledge and behaviour. In politics, especially in the representative democratic system, accountability is a crucial factor in determining good governance, and hence the legitimacy of power. The election of state representatives requires a responsible attitude to the public (Abd Aziz, 2003:68) (Note 2). Therefore, every action that has been taken needs to be explained to the public or the local community. According to Tantuico (1994), the ex-Chairman of the Philippines Audit Commission, accountability is the foundation to integrity and is the actual portrayal of the ruling government regardless of the form of ruling system which is used.

The Malaysian Constitution also speaks, directly and indirectly, on the accountability especially when it involves public property. Auditing is a form of 'check and balance' process which is important to determine whether a monetary transaction of an institution is running well (Abdullah 2004). The Constitution and the National Audit Act provide certain powers to increase the level of auditing and further on the level of accountability especially in public sector. This can be seen in Article 106 and 107 from the Constitution which explains the role and responsibility of the OAG to audit the budget and expenditure at all governmental levels.

The development of the audit system in Malaysia depends primarily on the changes and the administrative pattern and national politics (Kulasingham: 1). A seminar paper titled "Role of Supreme Audit Institutions in National Development" sees the national development at four stages, namely, (a) maintenance phase - the government gives importance to legal matters and procedures apart from basic services. Emphasis is more on regulatory and compliance, (b) mobilization phase - efforts and the governmental budget is directed towards the utilization of resources by preparing incentives for the infrastructure incentives and industrial base, (c) guidance phase - industrialization and privatization in development. Budget is focused on cost and program effectiveness, and (d) co-ordination phase economy has reached the mature level and is focused on welfare matters towards the community. Concern is directed 
towards the distribution of wealth and services in a just manner. The national budget is directed towards product and the manner of provision. It takes into account effectiveness and the program impact. The theory centred upon is exact in the context of the national audit system. It is undeniable that the audit system focus has experienced a change and development slowly, beginning with control, financial flexibility, economic, effectiveness and currently accountability (Note 3). According to Abdullah Sanusi et al., (2003), two different audit parts have been identified in the public sector. Firstly, the monetary audit-to evaluate the extent of the system's reliability based on the financial regulations in place. Secondly is the audit attainability. This section emphasizes on the effectiveness aspect and efficacy on the use of sources to produce a high return and the agreed objective. The legal amendment in the Audit Act 1957 also inserts accountability elements as a precondition to check on the government organizations' achievement.

\section{The role of auditor general}

The Auditor General (AG) forms an important function in the process of national accountability. His role is wide as stated in the Constitution in Article 107; the AG is not merely the auditor to the federal government, but also to the other 13 states. The audit system that exists directly creates a relationship and a chain of accountability (Kulasingham, 1986:1). In performing his functions to audit, his roles are to (a) ensure all forms of protective means towards assets and public property, (b) maintain all accounts and records, (c) give views on the national monetary statement and government agencies, (d) inspect comprehensively all the economic methods and the level of efficacy of a particular program, and (e) report to parliament and the relevant management team (Kulasingham 1986: 3).

According to the procedure, every financial statement of the government must be submitted to the AG in seven months after year end. If he does not receive any report in the appointed time, the AG will make a report to the King of Malaysia (hereafter YDPA) and there onward to the parliament. Three months are usually a normal time frame for the processes of checking and auditing. Up till now, there is yet to be legal practice that states the limit on the time frame for checking. Nevertheless, since the late 1980s, the problem of delay in submission of reports no longer exists. This is pursuance to the government press on under the governance of the previous Prime Minister, Dr Mahathir, in implementing the surveillance and sending reminders to submit reports right on time (Abdullah Sanusi 2003 et al.: 177). Apart from that, to ensure that his function runs smoothly, the law also protects him through various ways (Kulasingham 1986: 4). For example, the Audit Act 1957 allows the AG to look at all records and government documents to be audited. All individuals may be called upon to explain to the AG if the necessity arises. According to Tan Sri Ahmad Noordin, the previous AG, the auditing process which he has been assigned to has never been disappointing (Abdullah Sanusi et al., 2003:176). All documents, even those regarded as sensitive, like the Internal Security Act and the Seditious Act are also sent for auditing. The AG can also direct any officer to undergo an inquiry and report to him thereafter. His last and most important function is to report his earnings to the parliament. Also on his discretion, he may even decide to forward the report to the YDPA instead.

Freedom to air views without being affected with the external factors like political pressure and fear of non continuance of contract poses a very heavy challenge. The AG is confronted with scandals of millions of dollars involved, sensitive and extremely confidential to certain parties because exposure may seriously jeopardize the National economy. His declaration to the public through his yearly reports frequently obtains wide interest as well as it tests his accountability and integrity (Note 4). The AG report from 1989-1992 had identified a few defects in the monetary management in various governmental departments. Amongst factors identified by Ahmad Sarji (1994), namely (a) expenditure over and above what was necessary, (b) extra allocation requested by appropriate agencies were not correctly spent, (c) auditing records were not updated, (d) stores and accounting assets were not appropriately managed, (e) internal control was insufficient where it concerned earning collection, and (f) management system towards development projects was weak. Even though the government has dealt with the defects above which were construed to incline towards financial management problems, such cases are still repeating. In such a case, the Administration and Modernization Planning Unit (MAMPU) was set up to monitor, from time to time, programs which were oriented towards control enhancement system, infrastructure development for financial management including giving recognition to the most effective agencies in managing finance, and also to ensure that equal importance was given to the modernized governance and training.

Apart from that, independence in finance management for example, staff recruitment and training must also be given. Up till now, there are still many audit institutions which need to rely on central government to recruit staff and other financial matters (Ahmad Sarji, 1994). Another issue that arises is the scope auditing powers. The AG's role which is to supervise public service performance will trigger a lot of discontent especially in the governance and administration sector. This feeling, according to Kulasingham (1986), must be pushed aside if it does not lead to confrontational relations and non-productivity. At the same time, the AG is also confronted with an auditing policy which in a way does halt the government's auditing power. Unfortunately, the government defends it on the basis of it being purely guidelines (policy matters) and it cannot be intervened with. Nevertheless, the 1985 Tokyo Declaration has specified the 
"Guidelines of Public Accountability" which recognized the role of auditing as part of policy planning and strategy to achieve the objective of development (ibid: 5).

\section{The role of head of federation}

According to the Constitution under Article 32(1), the King of Malaysia (Yang Di Pertuan Agung, YDPA) is the Head of Federation for Malaysia. His Majesty takes primacy above all the rest of the people in the stated including the Queen, the second person after the YDPA, the other kings and the other heads of states (Mohamed Suffian, 1984:31). Nevertheless, this position is not a part of the Executive (Note 5). It is a symbol to the Executive (Abd Aziz, 2003:51). This symbol gives a very wide meaning in the institution of the federation ever since independence (Note 6). However, from time to time, the institution of the monarchy needs to be strengthened and revised to ensure it is still relevant with current needs which are more challenging (NST, 9/5/2005). Even though the Constitution has listed out the roles and functions of the YDPA, it must be understood that the document cannot be interpreted literally and formally. It cannot be seen as a normal statute. The reality is that there are some powers not elucidated in the Constitution and these powers may be used if the situation is grim (Abd Aziz 2001: 57). It cannot be denied that rooms for interpretation that exists within the spheres of the Constitution have in a way shaped the actions of the government. At this time, the institution of the Monarchy is the most unique and special platform to check and balance the accountability of the Executive (Abdullah Sanusi et al., 2003:179). At every meeting at the Parliament, for example, the Prime Minister will need to address the YDPA about related issues of the government. With his Majesty's position which is traditionally respected, the YDPA can influence the government to act with accountability. The Constitution also allows the YDPA to obtain relevant information with regards to affairs of the states (Abd Aziz 2006:53) (Note 7).

According to Raja Nazrin (The Star, 30/11/2005), the monarchy system practiced in Malaysia has fundamentally contributed to the way of democracy and governmental accountability in the country. This can be seen from the non-partisan institution of the monarch, placing it in a unique status over and above the political sentiments, ideologies, ethnics, religions and others. "It is a force for moderation over extremism" (ibid). This status positions, His Majesty as the best symbol for authority and power. That is why he is regarded as the main protector. Further, the role of the YDPA gives an extra room to the government to rule and promote democracy. This can be seen from the function of the YDPA in Article 40 where he acts according to the advice of the cabinet members or ministers. "Acting according to the ruling government's advice" does not portray a defect in of power but it is a manifestation of democracy (Abd Aziz: 53). It opens room for better trust of the public towards the ruling government and further validates the position of the ruling government. Also, in the context of democracy, it is wrong to place power in the hands of various persons in power for fear of power struggle leading to chaos (Note 8). The role of the YDPA and relations with the ruling government can also be explained in the context of constitutionalism and limited government. Both concepts are inter-related and emphasize the issue of governmental power that needs to be limited so the rights of the subjects are protected.

Apart from the role of the YDPA acting on advice of the government, His Majesty also has powers and other functions that can influence the actions of the government (p. 53). Article 40(2) states that the YDPA has the discretion to appoint the Prime Minister, dissolve the Parliament, and call upon the Kings' ceremonial meetings. The term discretion in the Article can be understood to mean the right of the YDPA to choose and decide what he deems best. This power of discretion is actually functional especially when the situation is very strained like what may happen after parliament has been dissolved (p. 54). So is the situation when the YDPA refuses to dissolve the Parliament. In a country that practices parliamentary democracy, the PM is given the extraordinary choice to select a date for election. In some ways, it is not good for democracy because the YDPA cannot control this. It is in such situation hence the need for the head of federation to ensure proper control and balance of power is needed (p. 55).

\section{The institution of parliament}

One of the fundamental principles for a democratic society is that the government must have accountability towards the people. In democratic countries which practice parliamentary system, accountability can be assessed through the role played by the Parliament. The Parliament is an institution that can maintain control towards the ruler where it acts as a "supervisor, a controller and a critic against the governance and it is capable to influence the policies of the government" (M Foad, 1999). Accountability can be derived from a question-answer session and a debate where the responsible minister is required to provide answers to every question forwarded. There are also written questions that need more detailed answers (Abdullah Sanusi et al, 2003). In other words, the process and procedures that take place in Parliament include the debates of preliminary issues and postponement speeches that all require the concerns of accountability.

In Malaysia, Parliament is the highest institution protected by the powers of the YDPA. Its main role is to make, amend and repeal the laws. Parliamentary members are given full freedom to debate and discuss various different current issues in the interest of the people and the country. However, this right is only confined in the noble House of Parliament. However, certain issues related to nationality, Bumiputra rights, the Malay language, monarchy and others 
are prohibited from being debated upon. These are protected essentials as enshrined in Article 63 and is part of the laws that must be adhered to by all members of the Parliament. Even though it is regarded as the most important fortress of accountability, certain questions arise as to the extent of efficacy of its functions. Many observers argue that over the years, the role of Parliament is declining and weakening. As stated by World Bank (2006), "Parliaments can play a crucial role in overseeing the actions of the Executive branch. Their power is built on the fact that they can hold state institutions accountable, represent the people at the highest level of government and exercise legislative powers..." Nonetheless, what the World Bank is suggesting here seems to be idealistic at least for Malaysia. The fact is that the executive has begun to dominate all the three organs, for instance in terms of law making sphere; Parliament seems to legitimate and not to legislate (Abd Aziz, 2001). To an important degree, the 'executive dominance' (Lim 2002b) has weakened the legislative accountability.

Shad Saleem Faruqi, the Malaysian constitution expert opines that the judicial process in Malaysia is viewed to involve the executive work rather than the parliamentary process. As evidence, $80 \%$ of drafts from 1991-1995 were passed without any amendments. From this amount, 15\% were altered because of pressures imposed by the NGOs and the other 5\% amended in the Parliamentary House. Its function is no more than a rubber stamp or formality to pass a particular proposition draft. This situation was even admitted by Mahathir Mohammad (1981), the fifth Prime Minister in his controversial book, The Malay Dilemma. For him, it is only a democratic practice that gives no meaning; in fact it gives more room to strengthen the governing party. From the aspect of conference and debate pertaining to the judicial aspect and finance, the parliament is seen as though to grant power to the minister to take a decision (Funston, 2001). This situation can create an unhealthy effect where the particular issue is only determined and dominated by a particular group only. The limitation faced by the opposition is also noteworthy in this context as Puthucheary (1978:127) notes, "generally the Opposition is regarded at best as unnecessary and at worst as evil." Consider the observation made by Chee (1991:110) "the Standing Orders of the House have been changed, over time, to the disadvantage of the opposition." According to Lim (2002b: 175), parliamentary reforms such as reviewing restrictive standing orders and ensuring greater impartiality have been suggested by the opposition, but to this day, have been ignored. Ong (1987) describes the parliament as follows:

Its overwhelming majority in the House has meant that its control of the Standing Orders Committee has been absolute. Thus, rules to limit the number of questions MPs were allowed to ask and the banning of adjournment speeches during key meetings of the House have tended to minimize the role of Opposition. Other sources of the strained relationship between the two were the limited time provided for Opposition motions, the shortage of the time given to study important bills and the lack of quorums in the House whether deliberate or otherwise (p. 53). Ong (1987) at some length has given an overview on how Parliament to a large extent failed to exercise the check and balance over the Executive due to its domination. Public Accounts Committee (PAC) deserves special attention as well as it is one of the key aspects of Parliamentary scrutiny. The existence of PAC can promote a culture of accountability in which it ensures ex-post supervision of the financial management process (Ofosu-Amaah et al., 1999). In Britain, PAC is chaired by the leaders of the Opposition parties, a tradition in which Malaysia has yet to practice. As such, the financial checks and balances seem to be lacking. Given this condition, it is believe that the appointment from the Opposition member as a Chairperson will provide more accountability and transparency.

\section{The doctrine of ministerial responsibility}

The doctrine of ministerial responsibility is important because it is the backbone of the cabinet system as practiced in the Parliamentary system. It has been observed as a constitution practice in the government based on the Westminster that ties the co-operation between parliamentary members so they can ensure that the current government elected constituting the people's representatives are responsible besides determining that every activity done at the ministry and department is being observed. The underlying principle is the entire governmental act, not the individual minister, is responsible. The responsibility of the minister takes two forms. Firstly, a collective responsibility that requires all ministers to be equally responsible towards all decisions of the other ministers. Secondly, the individual responsibility towards whom each minister has placed his/her portfolio in his/her roster. Every minister must be responsible upon every action taken by the public servants directly under his authority (Abd Aziz, 2006:123) or even for actions not known to him.

Even though this doctrine has been implemented since 1955, the practice is still not without faults. The direct implication of this collective doctrine is that it bounds all members of parliament to take a parallel stand with that of the party he/she represents. Even though it has the positive side of concretizing the party, it does not actually deny the autonomy against the stance of the party's members. There have in fact been some instances where actions were taken against parliamentary members who did not cohere with the party. The example is the suspension of Datuk S. Sothinathan, Deputy Minister of Natural Resources and Environment who questioned the government's stance, and issuance of warning letters to two Parliamentary members, Datuk Bung Mokhtar Radin (MP-Kinabatangan) and Datuk Mohamed Aziz (BN-Sri Gading) for supporting a motion by the opposition (NST, 10/5/2006). Another example 
was the case of Datuk Shahrir Samad whose position as the Chairman of the Government Supporters Club was withdrawn because he supported a motion given by Lim Kit Siang, the opposition leader. According to Datuk Shahrir, his action was meant to rouse the government so that it hears the opinions of the Parliamentary members and not sideline them. He also suggested that there should be guidelines given to Parliamentary members on what they could do and couldn't do based on proper ethics and integrity and not through the law as the current practice is $(N S T, 7 / 3 / 2006)$.

Furthermore, in the recent years, this doctrine has been eroded in many Commonwealth countries, including Malaysia. This is because there is no particular mechanism to ensure its implementation and as a result, the doctrine has instead been used by the government to defend its position from erosion, for example, when discrepancy occurs in views and the explanation provided for an issue involves the government policy. Occasionally, there will be excuses such as "we don't know" when abuse of power occurs (ibid). The situation is aggravated when the masses and the media themselves give different perspectives which indirectly portray the inefficiency of the parliamentary collective role (Abd Aziz, 2003:75).

\section{Ombudsman}

Ombudsman originated from a Swedish word that means a defender or agent. It has existed in the European countries like Sweden, Finland, Denmark, France and many others. Ombudsman is also known with many other different terms like Parliamentary Commissioner, Human Rights Mediator and others. Even though the terminologies differ, the concept that is introduced is the same, which is "to observe the actions of the authorities and improve any defects in an unfair administration towards the people" (Sanusi, 2000). Ombudsman can be defined as "a department or a body instituted through the constitution or the legislative assembly or the parliament headed by a high ranking public officer who is non-partisan who can be responsible to the legislative assembly or the parliament, who accepts complaints from anyone who has grievances against any agencies, officers and employers, or those who act independently to investigate and recommend solutions to improve the situation and produce reports" (Sanusi, 2000).

In Malaysia, the suggestion to have the Ombudsman has been discussed for a very long time; in fact, it was discussed even from the time of the late Tun Abdul Razak. On 23 July 1971, the Ombudsman system in the Malaysian version, which is the Public Complaints Bureau (PCB), was set up. It was placed under the Department of the Prime Minister. The PCB has grown from time to time. It gave the opportunity to the public to complain of their dissatisfaction against all aspects of administration of the government except any issues that have been determined as the policy and underlying principles of the government (Normawati, 1997).If seen from the viewpoint of the objectives for the setting up of the system, it can actually increase the quality of administration, protect the rights of people and guarantee transparency, fairness, accountability and good governance (Sanusi, 2000). This is because the public do not have any hindrance to see, read and analyze all files, reports and decisions that are made.

Sharifudin (1992) explains that to ensure the transparency and accountability through the system of Ombudsman, it should have the following features. Firstly, it should be appointed by a legislative body and not the executive. In fact, it should be responsible to prepare reports to the legislative body. Secondly, it is set up through the constitution to ensure that it is independent and non-partisan. Thirdly, it is empowered to investigate whether or not it is based on a complaint or its own initiative. Fourthly, it is empowered to ask and see governmental documents and finally it is empowered to criticize and reprimand the concerned officer and agency, seek for corrections to be made and thereafter reveal the truth to the public.

Lately, there have also been suggestions that the ombudsman should be set up again. In fact, the PCB Board of Advisory is said to be studying this suggestion to investigate misconduct amongst the implementing agencies including the elected representatives and ministers. The issues that arise bring forth the possibility whether the PCB fails to perform its actual function. According to Lee Lam Thye (NST, 2006), PCB's role was only to channel complaints to a particular different channel. He adds the need of the PCB to be upgraded to the role of an ombudsman. In fact, PCB is said to be very restrictive in its powers because it is placed under the supervision of the Prime Minister's Office. Sanusi (2000) also feels that it is not able to ensure the accountability in the exact manner because it is headed by a government officer who is bound by the rules and interest of the government.

Furthermore, Ranita (NST, 2006) also opines that one of the most important criteria in Ombudsman is accountability where it should present a report and be involved in the Parliamentary process, so the report can be shared with the public. This is a very important procedure because it ensures that it is free from the government, free from political interests and can perform its mandate free from any disturbances. She also voices her concern with any efforts to alter the state of the PCB to an Ombudsman because this bureau is one of the governmental bodies that is empowered by a public officer. Ramon Navaratnam also opines that it is fundamentally important that the Ombudsman should be a non-partisan institution which is free from any political influences so it can maintain the public's welfare and its accountability. As he puts it, "If the Ombudsman is not given any 'teeth', it will end up being just another advisory body and public confidence will be eroded" (NST, 10/4/2006). It is hoped that the principle of accountability through 
the Ombudsman can increase the public's confidence towards the administrative practices and also reduce the abuse of power, breach of trust and others.

\section{Election}

What is the relation between accountability and the elections? Who are the important groups in this system? And how is the accountability maintained? Cumaraswamy (1987:130) notes that democracy in essence means "government by the consent of the governed". One way to ensure this is through election. It is generally known that the election through a democratic process can actually change the foundation of a legally elected government. By having regular elections which are free and fair will open space to achieve the needed objectives. Besides that, regular elections grant a valid mandate to the government that exists. Since independence until now, elections have been held rather consistently and successfully. Nonetheless, as Lim (2002:185) notes, the practice of election in Malaysia "is not generally loose but is especially weak in the Malaysian executive dominated polity." In Malaysia, where the National Front, Barisan Nasional (BN) has always been in power and electoral constituencies have been gerrymandered repeatedly to their advantage making them as the sole beneficiary from the first-past-the-post system. Time and again, the BN maintained its two-thirds majority, which allows them to make Parliament as a mere 'rubber-stamp'. Even though the BN still remains as the governing party every time the elections are held, the total of mandate received always changes and adds to the integrity of the elections procedures. For political parties, it opens channels for every party to compete to draft the best formula to win comprehensively at the national level (Berita Harian, Feb/2002).

The election system is not merely static and totally dependant on Election Commission (EC). According to Abdul Rashid (Berita SPR, 2004), to view the level of achievement of elections in Malaysia, there has to be other comprehensive studies on the methodology of the Federal Constitution and also legal drafts that have shaped the climate of elections. Furthermore, socio-political factors also shape the ambiance of elections. As an example, a quasi democratic country with non-electoral laws is recognized by the chairman of the EC to hinder the principles of fairness and independence in elections that is instrumental towards a good election (Francis Lok Wah \& Khoo Boo Teik, 2002: 5). Abd Aziz (2003:223) explains that other organizations are also accountable in influencing the electoral system in this country. This includes civil service, judiciary and the mass media. Thus, the relations between accountability and elections do not affect only EC but also aspects of governance that encompass the legislations of policies and laws, rights and responsibilities of citizens and political leaders, government agencies and the mass media. In other words, all these units are instrumental in creating accountable environment of healthy elections.

In the context of our modern democratic state, voting is no longer deemed a privilege but a right of every citizen. In Malaysia, voting is not made compulsory on all citizens. However, even though voting is not made compulsory on every citizen, it does not entail that an eligible candidate who chooses not to vote is released from his responsibility. Abdul Rahman (Berita Harian, 25/8/2006) has reprimanded the political culture especially of the Malay community who that generally, though having deep interest in politics, are not consistent in their readiness in doing their political responsibility that a voter should actually do. The Chairman of EC, Abdul Rashid said that approximately 4.5 million Malaysians, comprising $70 \%$ of the population have not registered as voters (ibid). Voting is perceived as the most effective power tool of the citizens; and if this trend continues, it is not impossible that the elected government does not reflect the voice of the majority of this country's population. If this happens, it will be extremely unfortunate for the democratic system in Malaysia.

Apart from the individual responsibility, EC, as enshrined in Article 113 of the Federal Constitution, is the statutory body instituted to conduct elections in the most honest, credible and unbiased manner. Based on the Reid Commission, EC is entrusted to carry out elections at parliamentary and state level and prepare and recount votes. In other words, EC is assigned with all actions taken except negligence. On the issue of appointment of SPR, it might be asked whether it is indeed non partisan. This is because this commission is appointed by the YDPA after consulting the Conference of Rulers). Nevertheless, according to the Chairman of EC, such issues do not form a major concern. What is more important is the commitment and integrity of the commission members. The Federal Constitution drafted by the Reid Commission did not specify any definite method for the appointment of EC members, instead places basic principles that are transparent and emphasizes on the confidence of the public (Abd Aziz Bari, 2003: 215). The independence of this institution is indeed maintained. The status and positions are granted to the members of the EC is analogous to the members of the bench especially in the scheme of performance and retirement (EC Act 1958).

Furthermore, questions arose too pertaining the fairness and independence of the electoral system. This is in pursuance to the commission's failure to respond to allegations of unfairness, misappropriation of public money and others. However, some of the allegations hurled at the Commission are outside the jurisdiction of EC. It is thus reiterated that all sorts of criticism, do not affect EC's functions and roles (ibid: 222). Doubts against the independence and integrity of EC cannot be blamed on EC alone; instead it must be viewed from the system in totality that includes other agencies like the civil service, judiciary, mass media and community. On that note, Yaacob (1978:210-215) has identified several important elements that contribute towards a healthy election: 
(a) Sentiments that portray the involvement of the civil service and civil management, thus concretizing the perception of the masses that indeed they are given the right and space to make and decide on the results of election.

(b) An environment where the government can handle changes without chaos and bloodshed.

(c) The existence of an independent judiciary which is crucial to adjudicate contentions with regards to the number of votes.

(d) The existence of an administrative body that manages elections in an honest, efficient and non-partisan.

(e) Improvement and a development in the system of political parties that provide other alternatives to voters.

(f) Readiness by political leaders and members to accept the reality of electoral results whilst respecting rules of the games.

To ensure that elections run in an independent and fair way, the role of the Courts is extremely important. The Courts are the only authoritative body that can ensure that laws are rightly enforced whilst reducing the manipulations and diversions. Nevertheless, an electoral system which is too dependent on the courts is also discouraged. An election system must have a built-in mechanism to handle problems that occur. It is generally accepted that the court system is inclined towards technical aspects that is perceived to be able to reduce the tendency to make decisions in a democratic manner that can be accepted by all.

According to Abdul Rashid (NST, April 10, 2006), there is no fraud throughout the management by EC in the elections. However, he did admit that irregularities still persist especially in the aspects of management of elections. Nevertheless, this weakness does not in any way affect the principles of independence, fairness and transparency. In order to handle this problem, the EC had formed the "Election Campaign Enforcement Team". The membership of this team is as follows (Berita SPR 1, 2004):

(a) Enforcement Officer (an official of the EC)

(b) A Representative of the Malaysian Police Force (Royal Malaysian Police, PDRM)

(c) A representative of the Local Council

(d) A representative of the political party who is appointed by the delegate or the election agent

The team's function is to ensure consistent surveillance of the election activities throughout the period of campaigning until the voting is over. In general, there are two most common mistakes done by the party or the delegate:

(1) Campaign materials that should not in any way touch the personal attributes of the delegate that may contain elements of libel, falsehood that triggers emotions of hatred, doubt and bring rise to animosity. All posters and banners must also have the names and addresses of those who produce them; and

(2) Talks/ speeches that do not touch personal issues or derogatory remarks and further lead to hatred, angst, animosity and has no relevance whatsoever in the interest of the elections.

The latest development is during the election in Sarawak on March 2006, when the EC had introduced the new election code of conduct that has been recommended for usage in the coming elections. This code has been viewed as comprehensive and is directed at creating good actions amongst all delegates, agents and election officials that reaches beyond the day of naming of delegates, campaigning, the voting day, counting process and the total of votes including the announcement of the election results. In the aspect of the use of posters and banners during elections, until today there has not been any restrictions on them, but is suggested that the use of these two items should be reduced and monitored to save space, time and money (Berita Harian, 15/5/2006). Undoubtedly, many quarters have questioned the accountability of elections in Malaysia unless there is an attempt to make a reform for the electoral system. Somehow, there is no sign of changing the electoral system soon. In fact, Lim (2002:142) maintains that there is no serious attempt that is able to force the 'UMNO-led government' to reform the electoral system even though there is dissatisfaction among the Opposition and its supporters.

\section{Non-Governmental Organizations}

Pivotally, external watchdogs have become an essential tool nowadays in overseeing the government actions. In most developed countries, these groups or better known as Non-Governmental Organizations (NGOs) or Civil-Society Organizations (CSOs) play active roles in checking the activities of the government. There has been a form of a new democracy (Note 9) where the people demand a political system that is fully participative of the people, has good administration and work processes that are more transparent and democratic (Hasmy, 2001:2). These demands are usually pursued by the middle class groups that are educated and aware of the development that occurs within especially actions undertaken by the government. The non-governmental organizations, apart from the political parties and the government, are perceived as alternative institutions that are the stimulus and catalyst to the shaping of a new democratic system today. 
From the philosophy of administration and governance, NGOs and the government have their own perspectives. The government sees the issue of administrative governance as a means to uphold the law and order for the sake of the people. On the other hand, NGOs from the 'pluralist polity' view see the administrative governance in its capacity to balance the executive powers and the protection of human rights. They also urge for a more open, efficient and transparent administration (Saliha \& Weiss, 2003:204). The conceptual differences in the administrative governance by the government and the NGOs will inevitably influence the action of both parties which will then become a stimulus to a new political culture in the country.

In Malaysia, there were at least 12 categories of NGO organizations that made to almost 53 thousand in total (NST, February 21, 1999). From this total, it can be divided into two categories. The first category is the NGO which is registered under the Company Act. The focus and orientation of these organizations are based on various signs and expertise comprising of all shorts of areas like religion, welfare, community, sports, business societies, common interest societies, cultural, union groups, social recreation and women (refer to Table 1).

The emergence and development of the NGOs in Malaysia can be linked with the political and socio-economic development in the country. From the political side, the racial conflict that occurred on 13 May 1969 was the culmination of all the racial confrontations that had built up between the Malays and the Chinese. This incident had stopped all means of open political participation (Chandra, 1977:2). Heavy political issues that had traces of racial elements were considered sensitive. Instead, political discussions on more universal issues like consumerism, and environment were encouraged.

Apart from that, social and economic factors also contributed to the growth of the NGOs. Rapid and strong economic growth did not mean that all the relevant institutions could fulfil the needs of everyone concerned. For example, since the 1950s, political parties were seen as the most effective. However, since the last four decades, most political parties were more inclined to pursue their own racial interest. This demarcation of the political parties' interests made it easier for the NGOs to fill in the vacuum and cross over the narrow line that favours some particular races only.

According to Makmor (1998: 62), the relationship between the NGOs and the government can be understood in two ways. Firstly, it is a relationship based on the principle of cooperation. The government has acknowledged the importance of building a good rapport with the NGOs. Issues on women's rights and their roles in the community are very dominantly advocated by the women NGOs. They act as advocates in the legislative system to ensure that women rights are well protected and elevated. The same thing happened in 1991, where the Ministry of Consumerism and Commerce had been set up following the strong commitment shown by the NGOs for consumers (Hasmy, 2001).

The signs of acknowledgement by the government towards the NGOS are beginning to appear themselves. For e.g., the members of MAPEN who were selected amongst the NGO members like Chandra Muzaffar, Jomo K.S, Tan Sri Ahmad Nordin and Choon Min Sou were assigned to handle the ground policies towards the end of the NEP era. Aliran was requested by the Special Panel for the Parliament to present the proposal paper which consisted, among others, related to the amendments to the Criminal Procedure Code, and the latest related to the unity in Malaysians (The Sun, 24/9/05). This NGO had actually received the special award for Transparency 2006 by the State Secretary for the activities and integrity that were pursued.

Lately the women issues have been given immense attention by the government. This was after the lack of support by the women after the sacking of Anwar Ibrahim (Lai 2003: 72). It can be safely said that UMNO Women and the MCA are the champions of the women issues. The women NGOs also used this opportunity to work hand in hand with the government towards this purpose. The best example is the National Council of Women's Organizations (NCWO), which is the main organization of 80 women groups, who had successfully conducted several meetings with the government even though they were on a very different agenda and premise. The same goes for NGOs who work in line with the opposition, like those embarked by the Women's Agenda for Change(WAC) (Note 10) and Women's Candidacy Initiative (WCI) (Note 11) (Martinez 2003: 77-91). Their signs are not merely confined to women but also for the government to be fairer and more transparent. From the occupational aspect, however, the activism of the women working groups has not reached a satisfactory level. This is because of the government's pressure on its own trade union or working group which in effect also stresses them. These are the loopholes filled by the NGOs to pursue their rights and goals.

The environmental NGOs are also amongst the NGOs perceived by the local civilians as caring and sensitive instruments towards the caring and sustainable development (Note 12). Most of these NGOs are more people based rather than profit based. Their focus is not just onto activities on the environment but also touches on the preservation of the aborigines and the local people on the use and management of natural resources.

The approach adopted by the NGOs is more inclined towards discussions rather than confrontational. This is so even when they wish to channel their opinions and advise the government especially pertaining to the environmental care. The views aired are usually concrete and scientific, and hardly traced with emotions and rumours (Ramakrishnan 2003: 
124). Since the last few years, the NGOs have raised several issues that have caused massive destruction to the environment produced by huge projects, including the National Forest, the Tembling Dam, Penang Hill and the Dam in Sarawak.

The role played by the NGOs has succeeded in raising awareness in the democratic practice in Malaysia. This follows the hope of the people who want a change in the system so it reflects more democracy to resolve more complex issues. It also demonstrates recognition for NGOs, where the government in the past was more autocratic is now seen more flexible to work together with the NGO leaders, whom previously were seen as too elite or worse, accused as being foreign spies.

\section{Mass Media and Freedom of Information}

In a democratic society, the media has been described as the "fourth power" or the "fourth estate" supporting the other three-branch system of government i.e., the executive, the legislative and the judiciary. Put somewhat differently, the media has a legitimate role to check on these branches (Ooi, 2000). The press has also been regarded as an informal external mechanism for public accountability keeping the government somewhat in check (Chee, 1991). Hence, to function effectively and responsibly in a democratic society, the press definitely needs to be independent (Thussu, 2005). Alexis de Tocqueville notes the following, "The more I observe the main effect of a free press, the more convinced am I that, in the modern world, freedom of press is the principal and, so to say, the constitutive element in freedom" (Schmuhl, 2000)

One must remember that the connotation of ultimate freedom for example globalization, sensational issues (like racism) and fundamental human rights are not necessarily the best model to be followed by the media practitioners. In fact on the contrary, it can jeopardize the harmony of a society and the peace of the country (ibid). Therefore, freedom per se without a responsible attitude contradicts the journalism idealism and professionalism. This premise lays the foundation for the environment of values and the coverage of a report and analysis given.

In most countries, including Malaysia, the media is considered as the leading force in disseminating information and to shape the people's opinion. The media is also responsible to educate and survey the government's performance and to expose any abuse of power (Abdullah Sanusi et al., 2003:188). In short, the media's role must be viewed in a holistic way that is to create a civil society who is informed and becomes a direct tool of a check and balance to the governmental system which is still in place.

"Rooting out inefficiency and corruption is viewed as the principal objective of openness and transparency in the government. Access to information renders the processes of the government more open and makes those in power more accountable to their people" (Krishnan, 2001). This statement brings to another important mechanism for any society seeking accountability in the government, freedom of information. Only a few countries have given their citizens the right and access to a significant amount of government-related information (Ofasu-Amaah et al., 1999). Among the countries are Sweden, Canada, and Hungary. Perhaps this could be one of the reasons why these countries remain at the highest ranking of Corruption Perception Index (CPI). The countries that restrict its citizens to the access of information have a tendency to withhold the information not only for legitimate reason but also to protect themselves from any wrongdoings. In a way, Malaysia is no exception, under Official Secret Act (OSA), the classification of a document or other information classified as official secret cannot be challenged in any court of law (Jomo \& Tan, 2006). Kim (2005:97) claimed that under the "protective shield of this Act, massive corruption and cronyism have flourished."

Several quarters have called for Malaysia to have Freedom of Information Act (FOI). Somehow, for the time being, it seems hopeless as the Minister at the Prime Minister Department, Nazri Aziz had told the Parliament that the Government has no intention to revoke OSA (The Sun, Sept 19, 2006) as well as initiating FOI (The Sun, Nov 26, 2005). "...A popular government without popular information or the means of acquiring it is but a prologue to a farce or a tragedy or perhaps both" (Ransom, 1968:392). So wrote the fourth President of USA, James Madison in 1822. This quotation reflects the relationship between democracy, accountability and access to government information.

However, in Malaysia, the awards of projects to contractors are often done without clear and transparent guidelines. Cases of Pularek and the project of North-South Highway provide obvious examples. The unfinished prisons complex in Kuching also deserved an explanation. As noted by the Editorial of NST (April 20, 2006), "An investigation by the ACA might bring to light other irregularities." This is why access to such information is vital as Vaughn (2000) comments that it will allow the citizen to challenge government's actions that they do not agree, seek redress as well as a serious reminder for government officials not to be involved in any misconduct or wrongdoings i.e., corruption.

\section{Conclusion}

Accountability is an ethical concept that is universal in nature and can be applied across all borders in the form of governance. It supports the principle of good governance which is founded on constitutionalism, limited government, check and balance and others. In Malaysia, various institutions and mechanisms, both formal and informal, and both internal and external, have been instituted with the objective to check and limit the government power. This includes 
several important positions in the country's governance, starting with the Head of the Nation, the Auditor General, members of the Parliament, the Parliamentary Accounts Committee and others. Lay persons represented by NGOs, trade unions, co-operative and others need to be more participative in other social activities. The same applies to the media which are seen as an important mechanism in manifesting the final objective and ambition of the government. Nonetheless, one has to admit that all these mechanisms also suffer from many limitations.

\section{References}

Abd Aziz B. (2001). Perlembagaan Malaysia; Asas-asas dan masalah, Kuala Lumpur: Dewan Bahasa dan Pustaka.

Abd Aziz B. (2003). Malaysian constitution: A critical introduction, Kuala Lumpur: The Other Press.

Abd Aziz B. (2006). Politik perlembagaan: Suatu perbincangan tentang isu-isu semasa dari sudut perlembagaan dan undang-undang. Kuala Lumpur: Institut Kajian Dasar.

Abdul Rahman S. (2006). Melayu sia-sia hak pilih pemimpin. Berita Harian.

Abdullah A.B (2004), Prime Minister's speech at the launching of National Integrity Plan, Putrajaya, April 23, 2004.

Abdullah S. (2006). Perlukah jawatankuasa ombudsman di Malaysia? Dewan Ekonomi.

Abdullah Sanusi A, Norma M \& Abdul Kuddus A. (2003). The Malaysian bureaucracy: Four decades of development, Petaling Jaya: Pearson-Prentice Hall.

Ahmad Sarji A.H. (1994). The civil service of Malaysia: A paradigm shift. Kuala Lumpur: Percetakan Nasional Malaysia Bhd.

Baker, S.B. (2000). Government accountability and its limit, Issues of Democracy.

Barret, P. (2001). Some current issues in accountability, public service and merit protection commission senior executive service (SES) Breakfast Seminar Series.

Berita Harian: A Malaysian newspaper.

Berita SPR 1, 2004.

Cumaraswamy P. (1987). Role of Executive.

Chandra M. (1977) Aliran Basic Beliefs, Penang: Aliran.

Chee S. (1991). Public accountability in Malaysia: Form and substance in Pradhan G.B.N, Reforma M.A (eds.) Public Management in the 1990s; Challenges and Opportunities, Manila: EROPA.

Election Act 1958 (1999). Kuala Lumpur: Government Printer

Francis L.K.W and Khoo B.T. (2002). Democracy in Malaysia: Discourses and practices, London: Curzon.

Funston, J. (2001). Malaysia: Developmental state challenged Singapore in Government and politics in Southeast Asia. Singapore: Institute of Southeast Asian Studies

Hasmy A. (2001). At cartography of governance exploring the province of environmental NGO's boulder perspectives on a perspective on NGO's. Paper presented at the Symposium on Cartography of Governance, University of Colorado on $7^{\text {th }}$ April 2001.

http://en.wikipedia.org/wiki/Ministerial responsibility. Ministerial_responsibility. (2006).

http://www.iim.com.my/ Membina Masyarakat Maju Acuan Sendiri. (2006).

Jomo K.S. \& Tan W.S. (2006). Privatization and renationalization in Malaysia: a survey. [Online] Available: http://www.jomo.ws/research/research.htm. (September 23, 2006).

Kim, Q. (2005). Where to, Malaysia? Petaling Jaya: Strategic Information Research Development (SIRD).

Krishnan, G. (2001). Increasing information access to improve political accountability and participation, [Online] Available: www1.oecd.org/daf/ASIAcom/pdf/Krishnan_rev.pdf. (July 39, 2006).

Kulasingham, L.T. (1986). Changing Role of the Auditor General-Issues and Problems. [Online] Available: http://www.asosai.org/journal1986/changing_role_of_the_auditor_general.htm.(October 2, 2007)

Lai S.Y. (2003). The women movement's in Peninsular Malaysia in social movement in Malaysia: From moral communities to NGOs. London: Routledge Curzon.

Lim H.H. (2002a). Electoral politics in Malaysia: 'managing' elections in a plural society in Croissant A, Bruns G, John M (eds.), Electoral politics in Southeast and East Asia, Singapore: Friedrich Ebert Stiftung.

Lim H.H. (2002b). Public administration: The effects of executive dominance in Loh K.W and Khoo B.T (eds.), Democracy in Malaysia; Discourses and Practices, London: Curzon. 
M. Foad S. 1997. Asas Politik Malaysia, Kuala Lumpur: Dewan Bahasa dan Pustaka.

Mahathir M. (1981). The Malay Dilemma, Singapura : Time Books International.

Makmor T. (1998). NGO in Malaysian democratic system, Massa, pp. 62.

Malaysian Federal Constitution. (2007). Kuala Lumpur: International Law Book Services.

Martinez, P.A. (2003). Complex configurations: the women's agenda for change and the women's candidacy initiative in Social movement in Malaysia: From moral communities to NGOs. London: Rutledge.

Milne, R.S. (1978). Politics and government in Malaysia, Malaysia: Times Book.

Mohamed Suffian H. (1984) Mengenal Perlembagaan Malaysia. Kuala Lumpur: Dewan Bahasa dan Pustaka.

Mustafa, K.A. (2002). Defining democratic discourses: the mainstream press in Francis L. W \& Khoo B.T (eds.). Democracy in Malaysia: Discourses and practices. Curzon: Nordic Institute of Asian Studies, pp. 138-164.

Normawati H. (1999). Undang-undang pentadbiran, Pusat Pendidikan Lanjutan, ITM.

NST (New Straits Times): a Malaysian newspaper.

Ofasu-Amaah W.P, Soopramanien R. \& Uprety K (1999). Combating corruption, Washington: The World Bank.

Ong M (1987) Government and opposition: the rules of the game in Zakaria Haji Ahmad (ed.), Government and Politics of Malaysia, Singapore: Oxford University Press.

Ooi, G.L .(2000). Singapore- Country Report in Media and Democracy in Asia an AMIC Compilation, Singapore: AMIC.

Puthucheary M.C. (1978) Ministerial responsibility in Malaysia in Tun Mohd Suffian, H.P Lee and F.A Tridade (eds.). The constitution of Malaysia, its development, 1957-1977, Kuala Lumpur: Oxford University Press.

Ramakrishnan S (2003) The environment movement in Malaysia in Social movement in Malaysia: from moral communities to NGOs, London: Rutledge.

Ransom H.H (1968) Secrecy, Defense and Democracy in Altshuler A.A (eds.) The politics of the federal bureaucracy, New York: Dodd, Mead and Company.

Regina W, Conversations: Analyzing Aliran. 2005. The Sun.

Saliha H \& Weiss M.L (2003) Social movements in Malaysia: from moral communities to NGOs. London:

Sanusi O (2000) Hisbah dari perspektif politik dan NGO, Majalah Detik.

Schmuhl R. (2000). Government accountability and external watchdog, Issues of Democracy, Vol. 5 (2).

Sharifuddin Z. (1992) Public service quality in Malaysia. Dewan Masyarakat.

Tantuico F.S. (1994) Accountability \& performance: Central pillars of democracy, Mandaluyong, Philippines: Fiscal Administration Foundation (FAFI).

The Star: a Malaysian newspaper.

The Sun: a Malaysian newspaper.

Thussu D.K (2005) Media plurality or democratic deficit; private TV and the public sphere in India in Romano A. and Bromley M (eds.), Journalism and Democracy in Asia, London: Rutledge.

UM Bulletin, (2004).

Vaughn R.G. (2000) Transparency- the mechanism: Open government and accountability, Issues of Democracy, Vol.5 (2).

World Bank. (2004) Social development: introduction to the concept and emerging practice in social development papers: participation and civic engagement. Washington, DC: The World Bank.[Online] Available: http://lnweb18.worldbank.org. (August 25, 2006).

World Bank. (2006) Strengthening bank group engagement on governance and anticorruption. [Online] Available: www.worldbank.org (September 2, 2006).

Yaacob H.M, (1978) Development in the law concerning elections in Malaysia in Mohamed Suffian, H.P. Lee \& H.P Trindade (eds.), the constitution of Malaysia-Its development 1957-1977, Kuala Lumpur: Oxford University Press.

Zaharom N (2002). The structure of the media industry: Implications for democracy in Francis L.W \& K.B (eds.). Democracy in Malaysia: Discourses and practices. Curzon: Nordic Institute of Asian Studies. pp. 111-137. 


\section{Notes}

Note 1. According to the Western society, the first stage of accountability emphasizes issues of management, efficiency and productivity. It is generally agreed that the public have the right to be informed on actions taken by relevant bodies entrusted with the power to implement. In this perspective accountability holds resonance to auditing which focuses on the result against costs used and the objective aimed.

Note 2. Article 39 of the Malaysian Constitution uses the term executive "authority" instead of executive "power". Authority has a different connotation from power. It postulates from a grant of position and is legally valid. In contrast, the term "power" connotes an influence that a person may have over another to do something. It means power that does not necessitate validity.

Note 3. The accounting discipline has evolved following the rapid changes that are taking place today. Inter-dependency with other disciplines, for example, economy, has introduced the concept of social accounting that restates the importance of value, professionalism, work etiquette and others in accounting.

Note 4. Since independence, numerous cases of non-compliance and extravagance had taken place. In the 1970s, a serious case of non-compliance implicating the Defense Ministry and Education Ministry engrossing almost RM100 million was made known. This trend continued even to 1990s but was still kept under lid. In 1997 however, a serious case was again identified in the Education Ministry amounting to RM800 million, including unpaid bills by the Police Department amounting to RM70 million following insufficient allocation in 1992-1997. In 1999, the AG also realized that following hasty planning, half on the 10,000 speed control gadget units for heavy transports bought at RM10 million could not be used. In the privatization sector, a concession for a support system in government hospital was found to be overdue and breached the conditions. Further, 2 separate hardware programs for the Health Ministry and the Traffic Police Department which each used up RM8.77 and RM48.47 million also could not function.

Note 5. Refer to the Federal Constitution which explains the YDPA and the role of the executive. Though both these matters were placed under the same Article, i.e. Federation, but they are stated in different sections- YDPA in Section 1 (The Supreme Head) and Executive in Section 3. Also, the YDPA's role can be seen as the fourth entity after the executive, legislative and judiciary (The Star, 30/11/2005).

Note 6 . Out of the 200 countries in the world, only 34 still maintain the institution of the monarchy as the head of state. Malaysia is one of them. Malaysia and Brunei are also countries with Muslims being the majority of population out of the 10 countries that retain the Sultanate tradition; a tradition from the Institution of Caliphate (UM Bulletin, 5/6/2004).

Note 7. This practice originated from Britain, but the value entrenched like the spirit of discussion and transparency is inherently good and can dispel autocracy (Abd Aziz 2001: 53).

Note 8. This theory discusses whether in the situation of anarchy, power can be passed to the people rather than the YDPA or to the courts which are perceived to be able to make better decisions. These choices are delayed and can place democracy and constitutionalism in a risky state (Abd Aziz 2001: 57).

Note 9. This new view in democracy has acceded to a higher and more positive plane - the civil society, in that it created a good relationship between the government and the masses. This view also supports pluralism by acknowledging the existence of masses units that accommodate the relationship. These units include the NGOs, political parties, media, trade unions, cooperation, religious organizations and others (Saliha \& Weiss 2003). NGOs are often cited in this civil function.

Note 10. WCA is the climax of the efforts taken by the women NGOs and is the catalyst for larger movements to improve social justice. It was founded during the political chaos when an alternative government was fought for, after the sacking of Anwar Ibrahim. Among the panels are Women's Development Collective (WDC), All Women's Action Society (AWAM), Sisters in Islam and several other individuals like Ivy Josiah, Carol Yong and others.

Note 11. WCI is seen as the pursuant step towards women's rights. It is also seen as a result of disappointment due to failing to change the position of women. A very distinct example is the Domestic Violence Act. Even though the Act is passed, the legislative process took more than 2 years including the lobbying and confrontation with the women NGOs.

Note 12. Among the active ones are Malayan Nature Society, the Environmental Protection Society of Malaysia (EPSM), World Wide Fund for Nature and Sahabat Alam Malaysia. 
Table 1. List of among the active NGOs and their inceptions in Malaysia

\begin{tabular}{|l|l|}
\hline Names of Malaysian NGOs & Year of inception \\
\hline Consumer Association of Penang (CAP) & 1969 \\
\hline Persekutuan Pertubuhan Pengguna Malaysia (FOMCA) & 1973 \\
\hline Persatuan Pertubuhan Pengguna Malaysia (EPSM) & 1974 \\
\hline ALIRAN (Kesedaran Kebangsaan) & 1977 \\
\hline Sahabat Alam Malaysia (SAM) & 1977 \\
\hline Suara Rakyat Malaysia (SUARAM) & 1981 \\
\hline Women Aid Organization (WAO) & 1986 \\
\hline Tenaganita (Suara Wanita) & 1990 \\
\hline
\end{tabular}

